\title{
The Role of the Islamic Research Academy (1961-1978 AD)
}

\author{
Ashraf Mohamed Abdul Rahmana, Samah Mohamoud Abdelrahman ${ }^{b}$, \\ Abd Elrahim Hamed Ahmed Mahmoud ${ }^{b}$ \\ ${ }^{a}$ History Department, Faculty of Education, Ain Shams University \\ b Tourist Guidance Department, Faculty of Tourism and Hotels, Minia \\ University
}

\begin{abstract}
The Islamic Research Academy is the normal extension of the Council of Senior Scholars that was formed by Law No. 10 of 1911 AD. The Islamic Research Academy is considered the connective between Al-Azhar and the outside world. The Islamic research academy was formed by Law No. 103 of 1961. It sends preachers to various parts of the world to call for Islam and uphold the word of God. In addition, Holding annual conferences to discuss the most important issues. They also help to solve the issues and problems of Muslims, spread the true Islamic religion, and repel the campaigns that aim to distort Islam.
\end{abstract}

Key words: The Islamic Research Academy, Al-Azhar, preachers, Islamic conferences.

\section{Introduction}

The Islamic Research Academy is the natural extension of the Council of Senior Scholars that was formed by Law No. 10 of 1911 AD $^{(1)}$. This law stipulated the tasks assigned to this body, for which it was established. Several other laws were issued to develop Al-Azhar Al-Sharif during that period since the issuance of Law No. 28 of 1920 AD up to Law No. 103 of $1961^{(2)}$. The latter abolished the Council of Senior Scholars and replaced it with the Islamic Research Academy, which is considered one of the most important institutions of Al-Azhar. It is managed by Sheikh Al-Azhar. He is appointed by the President of the Republic. Members of the Academy are appointed by the President of the Republic based on the proposal of the competent minister and Sheikh Al-Azhar ${ }^{(3)}$.

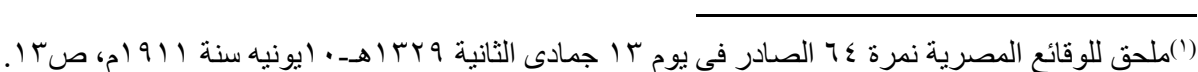

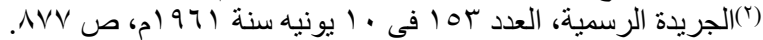

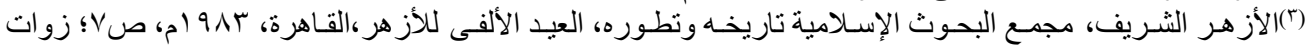

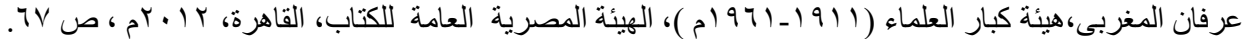


The Islamic Research Academy is considered the link between Al-Azhar and the outside world. It sends preachers to various parts of the world to call for Islam and uphold the word of God. In addition, they help to solve the issues and problems of Muslims, spread the true Islamic religion, and repel the campaigns that aim to distort Islam. Al-Azhar also welcomes expatriates from all over the world and qualifies them to form the bases for launching the Islamic call. Gradually, the relations of the Academy with the Arab and Islamic cultural centers in Africa becomes stronger.The Academy worked to provide these Islamic centers, bodies, societies, universities, and institutes with religious references, cultural books, school courses and curricula ${ }^{(4)}$.

\section{The important role of the Islamic Research Academy}

The Islamic Research Academy, the mouthpiece of Al-Azhar, who speaks truth and guidance. Its preachers work everywhere, so it was necessary to develop Al-Azhar and enact laws that enable it to accomplish its goal. Therefore, there was an urgent need for the Islamic Research Academy due to the new developments that have happened lately to the Islamic community, as a result of the modern life in which society lives. Such developments need urgent and decisive solutions in order not to allow the commons to express their independent opinions on them, regardless of their knowledge of religion and life ${ }^{(5)}$.

Undoubtedly, the Islamic Research Academy works and practices its activities in conditions different from those of the Council of Senior Scholars as the Academy worked in the proper environment after Egypt's liberalization from foreign influence. When most Islamic countries freed from foreign colonialism, Sheikh Al-Azhar, Sheikh Mahmoud Shaltout(6), worked to establish the Islamic Research Academy after the Law of Development in AlAzhar to be a reference for Muslims. On forming it, he took into account that

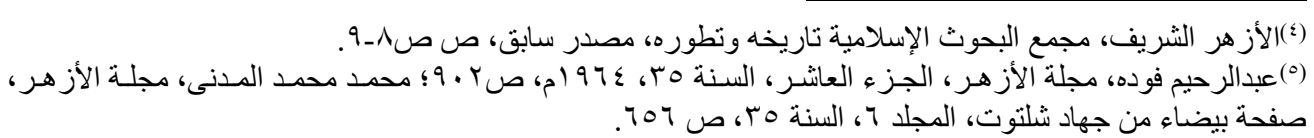

(6) Sheikh Mahmoud Shaltout was born in the village of Bani Mansour, Itai Al-Baroud, AlBeheira Governorate. He memorized the Holy Qur'an, then he was educated at Alexandria Institute, that he joined in 1906. He obtained al-'Alameya Certificate in 1918 and worked as a teacher in Alexandria Religious Institute in 1919, the year of the Egyptian revolution, so he strived with his pen. In $1946 \mathrm{AD}$, he was appointed as a member of the Academy of the Arabic Language, and in 1950 he became the general observer of Islamic culture and research that he improved and established communications with the world.

In $1957 \mathrm{AD}$, he was appointed as a deputy of Al-Azhar Al-Sharif, and he became "Sheikh Al-Azhar" in 1958. During his reign, Al-Azhar Development Law No. 103 of 1961 was issued. He died in 1963 AD.

- ( للمزيد انظر محمد عبدالعليم حسين، مشيخة الأزهر الثريف، الأزهر الثريف فى عيده الألفى، القاهرة، به 19 ام، ص 
it has to represent all Islamic madhhabs (schools of thought). This time is considered the most appropriate to establish the Academy and the most appropriate conditions for free Islamic studies that manifest the reality of Islam and the distortion it is exposed to. All these conditions necessitated forming a major body that searches, studies and delineates solutions in the light of its diverse neutral cultures without restricting its fatwa or call to a specified individual $^{(7)}$.

The Research Academy is considered one of the most important institutions that emerged after the Development Law. Article 10 of the law defined the role of the Academy, as follows:

- Research and study of all that is relevant to Islamic research and studies Work to revive Islamic culture and purify it from curiosity and erroneous information as well as the effects of political and sectarian intolerance by manifesting its pure original essence.

- Following up all researches and studies published on Islam and Islamic heritage both locally and abroad, to benefit from correct opinions, or refute the incorrect with the accurate response.

- Researching and studying all new doctrinal, economic and social problems related to belief or other and clarifying the Sharia opinion in them.

- Attention to the Islamic heritage and working on its dissemination and application on the ground.

- Assuming the responsibility of calling for God's path with wisdom and good advice, besides considering the affairs of Islamic call at home and abroad.

- Setting the rules for competitions, scholarships, and awards that are guaranteed by the state in order to encourage Islamic studies.

- Drawing a system of Al-Azhar scholarships and missions to the world, and vice versa.

- Holding annual conferences to discuss the most important issues and developments on the scene and following them by the concluded enforceable decisions and recommendations ${ }^{(8)}$.

The Islamic Research Academy assists Al-Azhar University in directing Islamic post-graduate studies for the two majors of (MA) and al-Alameya $(\mathrm{PhD})$ degrees, supervising them and participating in their exams. The Academy performs its mission within the framework of the comprehensive

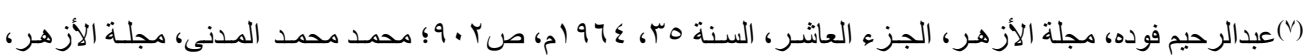

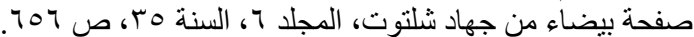

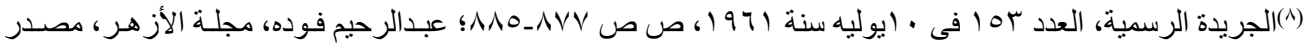

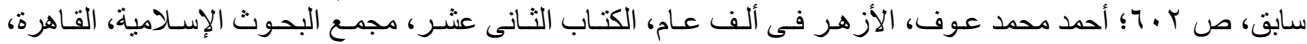

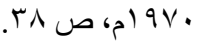


message of Al-Azhar through its council headed by Sheikh Al-Azhar and its various departments. The Islamic Research Academy consists of (50) members of the Senior Scholars of Islam. They represent all Islamic schools of thought, of which no more than (20) are not citizens of the ARE. Dr. Mahmoud F. Hoballah ${ }^{(9)}$ is the first general secretary of the Academy ${ }^{(10)}$.

Several committees were formed from the board of Islamic Research Academy in accordance with the law from its members, each of which specializes in a discipline of Islamic culture. These include:

Firstly: The Qur'an Research Committee to study the issues of reciting the Holy Qur'an and interpret it simply. It will collect a book on Qur'an recitations or readings, and compiling the encyclopedic dictionary of the Holy Qur'an.

Secondly: The Noble Prophet's Sunnah Research Committee to investigate the Sunnah's books, explain the hadiths, and explains their actual meanings and objectives.

Thirdly: The Fiqh (Islamic Jurisprudence) Research Committee to supervise several sub-committees and carry out their activities in codifying Islamic Sharia.

Fourthly: The Doctrine and Philosophy Committee to search the topics of existence, the terms of Sufism and the renewal of IIm al-Kalām (Islamic scholastic theology),

Fifthly: The Islamic Heritage Revival Committee to undertake the project of publishing the documents and covenants that include rational guidance in the field of Islamic governance and civilization.

Sixthly: Committee of the "Encyclopedia of Islam" that compiles the items dealing with the proper names, places, etc. according to their alphabetical order.

(9) Dr. Mahmoud Hoballah was born in 1903 in Beheira Governorate. He memorized the Noble Qur'an and joined the Desouk Institute, then the Alexandria Religious Institute. He got Al-'Alameya certificate in 1929 and was appointed as a teacher at the Alexandria Religious Institute. He obtained a doctorate from London in 1943 AD and returned to teach in the Faculty of Fundamentals of Religion. He traveled to Washington as a director of the Islamic Center. He was appointed director of the Islamic Center in London in 1956 AD, then he was appointed Secretary-General of the Islamic Research Academy in 1963. He remained in this position until 1968.

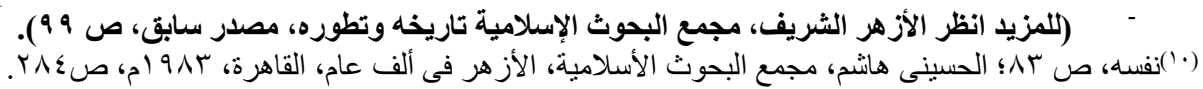


Seventh: The Committee for the Definition of Islam and the Committee for Jerusalem and Islamic Minorities ${ }^{(11)}$.

The Islamic Research Academy organizes conferences that discuss various issues of Muslims around the world, including the African countries. The Conference of Muslim Scholars held annually by the Academy is considered one of the most important forms of its executive activity. The Academy held eight conferences since 1964 until 1978 to discuss several important issues (12).

It initiated its activities by holding conferences in 1964, and presented a set of researches that dealt with various aspects of Islamic thought, life, and important issues faced by Muslims throughout the Islamic world. It was keen to issue its researches in both Arabic and English. In addition, it kept them in volumes in Al-Azhar Library, each of which includes a collection of researches that were delivered in its annual conferences to facilitate benefitting and publishing them ${ }^{(13)}$.

The Islamic Research Academy includes several research platforms and organizational departments specialized in various religious sciences and all affairs of Al-Azhar Al-Sharif. These departments include (General Administration of Foreign Students, Islamic Missions City, Al-Azhar Foreign Institutes, General Administration of Islamic Missions, General Administration of Research, Authorship and Translation, Fatwa Committee, Al-Azhar Books House, Islamic Heritage Revival Department, Al-Azhar Magazine, Supreme Committee for Islamic Call).

These departments coordinate to improve the scientific research in Islamic studies, renew Islamic culture, spread Islamic heritage and culture all over the Islamic world. At home, thousands of preachers are spread in the cities of Egypt and its villages for preaching and religious guidance. In addition, AlAzhar sends its teachers and preachers to the African countries to spread the various religious sciences under the supervision of the administration of Islamic Missions in Al-Azhar in terms of their selection and qualification (14).

In $1967 \mathrm{AD}$, the Islamic Research Academy managed to study the preparation of an interpretation of the Holy Qur'an so that it may be translated into foreign languages to help non-Arabic-speaking Muslims in all countries of the Islamic world. They examined the idea of establishing an

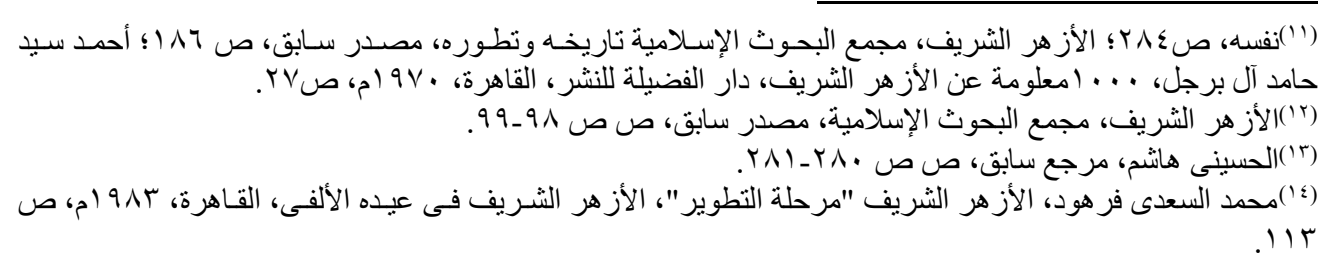


international association for Al-Azhar graduates to carry out its mission in defining Islam, strengthening communication between Al-Azhar and its affiliates throughout the world and revive its global role. This association aims to communicate with thousands of Al-Azhar graduates who are abroad. It also aims to provide scholarships, care for expatriates and work to know their problems and search the best solutions for these problems ${ }^{(15)}$.

After fourteen centuries since the beginning of the revelation of the Holy Qur'an, the Islamic Research Academy has taken scientific steps to develop a Qur'anic encyclopedia. It aims to include all information about the Qur'an, propose topics for writing on them scientifically, and investigating and publishing scientific manuscripts related to the Holy Quran and its sciences. The Council of the Islamic Research Academy issued a recommendation to all reciters of the Qur'an to commit to one reading in the same council in public forums, radio, television, and recitation councils that are not intended to teach Qur'an readings. This aims to avoid the improper mixing and confusion of different readings to listeners ${ }^{(16)}$.

In 1969, Sheikh Abdel Halim Mahmoud ${ }^{(17)}$ was appointed SecretaryGeneral of the Islamic Research Academy and worked to reconfigure its committees. So, he established four committees affiliated to its General Secretariat, namely- :

(1)The Committee of "Encyclopedia of the Sunna". It included professors such as Sheikh Muhammad Hafez, Sheikh Abd al-Rahman al-Zoghbi and Sheikh Abd al-Hamid Nada. It proceeded its work in verifyingthe work of Imam al-Suyuti entitled "Al-Jami' al-Kabir", of which it has four copies in the form of photosand manuscripts.

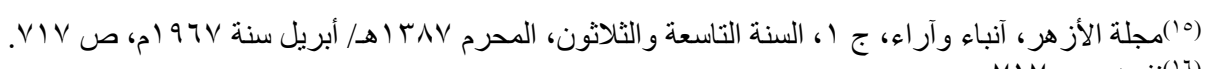

(17) Sheikh Dr. Abdel Halim Mahmoud was born in 1910, he studied in the higher section of Al-Azhar Al-Sharif, and obtained a doctorate from France, and returned to be appointed as a teacher of psychology at the Faculty of Arabic Language. Then, he became a professor of philosophy at the Faculty of Fundamentals of Religion, then he became dean of the faculty. In addition, he contributed to many philosophical and scientific conferences held in Islamic countries, and participated with his researches and efforts. He gave lectures on radio and television, and was chosen to head the committee for the explaining the Qur'an in the Supreme Council of Religious Affairs, as he was appointed a member of the Islamic Research Academy, then its secretary in 1969 AD. He became the minister of endowments, then an deputyof Al-Azhar. He became Sheikh al-Azhar in 1973. He published his story translated from French by André Morowa in 1946 AD, then he continued his prolific literature until his death in 1978 AD.

- اللمزيد انظر محى الدين الطعمى، أسلاك الجوهر فى طبقات المعاصـرين مـن شـيوخ الجـامع الأزهر ، دار المعـارف، 
(2) Committee of the Qur'anic dictionary that consisted of Sheikh AbdelMuhaimin Al-Fiqi, Sheikh Ismail Al-Tahhan and Sheikh Muhammad AlSunbati.

(3) The Committee of Islamic Encyclopedia that consisted of Sheikh Mohamed Ahmed Hassanein El-Sharkawy, Professor Mohamed Kamal ElSayed (for English), Professor Mohamed Abdel Latif Abdel Aziz (for Hebrew), Professor Fathi Mahmoud Youssef (for Persian), Professor Mohamed Agami and Professor Ibrahim DesouqAbdo (for French).

(4) The Shari'a Codification Committee that consisted of professors: Al-alSayyidSayyid Rajab, Muhammad Abdo Al-Beheiri, FahmiAbd Allah Sayed Ali and Abd al-TawabAbaza. The council of Academy may, when necessary, form temporary committees ${ }^{(18)}$.

In $1970 \mathrm{AD}$, a Republican decision was issued to appoint Dr. Abdul Rahman Bessar ${ }^{(19)}$ a secretary general of the Islamic Research Academy. He was concerned with the external role of the Academy to be able to spread the Sahih of Islam and religious culture all over the world. Hence, Sheikh Abdul RahmanBessar paid special attention for Africa, and sent the Azharite envoys to various regions of the continent. In addition, he sent many Islamic books to Islamic centers in Africa, and established postgraduate studies at Omdurman Islamic University, Sudan ${ }^{(20)}$.

The Islamic Research Academy cooperates with the African religious institutions on many issues to enable them to play role in disseminating various religious sciences. The Academy works to spread the correct Islamic call in Africa to repel Christianization. It issues its various statements on the opinion of Islamic Sharia on the issues raised on the local and international scene, as well as the persecution of Muslims in some African countries ${ }^{(21)}$.

It is stated that the Islamic Research Academy carries out its functions through some departments and committees, whose most important efforts in this regard can be divided into the following: -

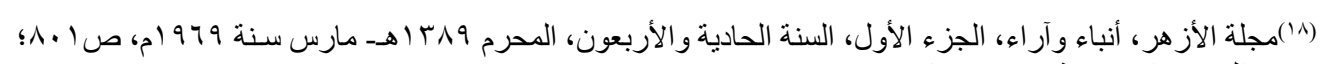

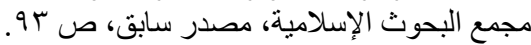

(19) He was in 1910 in Kafr El-Sheikh Governorate, he got al-'Alameya certificate from the Faculty of Fundamentals in 1939. He got a doctorate in philosophy in 1945, and was appointed as a teacher at the Faculty of Fundamentals of Religion in 1949, and became a professor at the same faculty in 1955, and deputy of Al-Azhar in 1974. Later, he became a Minister of Public Endowments in 1978, and was chosen as director of The Islamic Center of Washington in 1959. He had many books, including a thesis on war and peace in Islam.

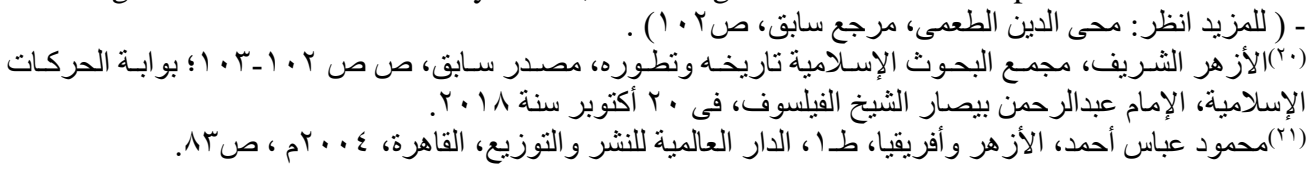




\section{First: Issuing a Monthly Series of Islamic Researches}

In line with the objectives of the Academy in disseminating Islamic culture, providing it easily for all, and helping the ordinary Muslim to have an Islamic library for small price, the General Secretariat of the Islamic Research Academy issued a monthly series of a new book presenting various aspects of Islamic culture ${ }^{(22)}$.

This series worked to provide the reader with Islamic culture. Considering a set of the books it published from 1961 to 1981, it appears that the series was issued along this period (92) books, (77) of them in the religious field, i.e., $83.6 \%$ of its production, ten books in the social field by $10.8 \%$ and four books in the political field by $4.3 \%$. This shows that the series dealt mainly with the religious issues, especially those that do not raise any sensitive issues in society. It also addressed important issues, including the persecution of Muslims in some African countries at the hands of the missionary campaigns $^{(23)}$.

The masses received this series well, and the readers insisted on issuing the series twice a month. So, the General Secretariat of the Islamic Research Academy agreed. It managed to publish the book of the series in the beginning and middle of the Hijri month. The Academy was keen that the books of the series should be of value, and some books were provided in several languages. The series issued some books such as ("Al-Aqida alIslamiya" by Sheikh Muhammad Abu Zahra, "Al-Quds fe al-Islam" by Dr. Abd al-Halim Mahmoud, "Al-Masjid Al-Aqsa" by Sheikh Abd alLatifMushahari,"Al-MokhaderatfeRa'y al-Islam" by HamedJame') ${ }^{(24)}$.

The Sheikh of Al-Azhar supported the efforts of the Islamic Research Academy to expand the publication and distribution of religious and cultural books as well as the Islamic Research Series. He received Eng. Ahmed AlSharabas, Deputy Prime Minister and discussed the religious affairs and education at Al-Azhar as well as the importance of increasing the distribution of the true Islamic religious books in Africa ${ }^{(25)}$.

\section{Second: Holding Annual Conferences}

The Islamic Research Academy takes part in the scientific activity of AlAzhar, i.e., holding Islamic conferences that it considers a part of its mission and an important indicator that clarifies the role of the Academy in society's

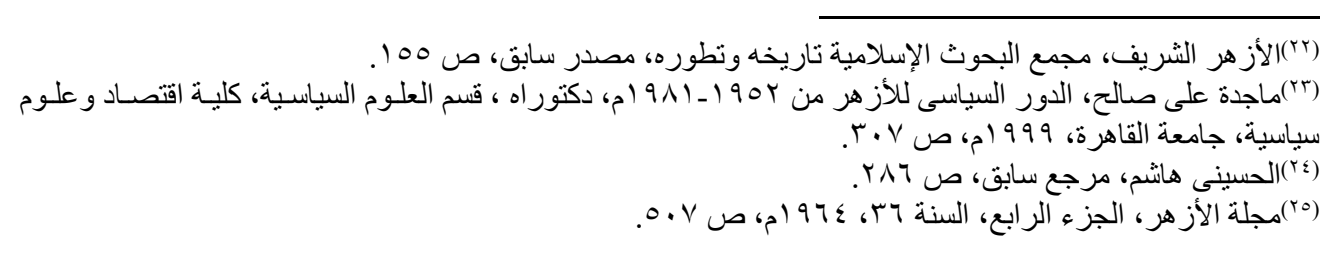


issues. These conferences are evidence of its activity, and their decisions and recommendations in conferences receive the appreciation and interest of Muslims in every place they are held. The decisions of its conferences and recommendations are of importance as they are issued only after being scrutinized by judicious Islamic scholars from various countries, which bestows upon them the status of 'ijma or consensus within the framework of Islamic Sharia. The Academy has assigned a committee to consider the Fiqh problems and try to find solutions to them with great flexibility, but within the framework of Islamic Sharia. In addition, the Academy assigned committees for codifying the four well-known Madhhabs separately ${ }^{(26)}$.

The mission of the Islamic Research Academy aims at the intellectual communication between Muslim scholars and the spirit of the age in which they live. The conferences held in Cairo and Africa for Muslim scholars upon the invitation of the Academy influenced the Islamic peoples and governments with their decisions and recommendations that dealt with the various aspects of Muslim life in our time. Hence, they put such decisions and recommendations into action ${ }^{(27)}$.

The Islamic Research Academy convenes at a regular meeting once annually unless it is necessary to hold an emergency meeting. However, this annual meeting does not take place regularly. These conferences are important indicators that explain the role of the Academy in discussing community issues. Eight conferences were held by the Academy from 1964 to 1977 and they discussed the important religious, economic and social issues ${ }^{(28)}$ during that period as follows: -

\section{(1) The First Conference}

The Al-Azhar sheikdom set a date for the first conference in Shawwal 1383 AH - March 1964 AD and the General Secretariat of the Islamic Research Academy took the lead in preparing for this conference. It invited nearly eighty intellectuals concerned with Islamic culture and Muslim affairs from all over the world. It also invited Muslim scholars from forty African countries, including (Libya, Tunisia, Algeria, Somalia, Nigeria, Mauritania, Senegal, Mali, Sierra Leone, Togo, Uganda, Kenya and South Africa). A large number of scholars accepted this invitation and the representatives of Al-Azhar Al-Sharif received them at the airport ${ }^{(29)}$.

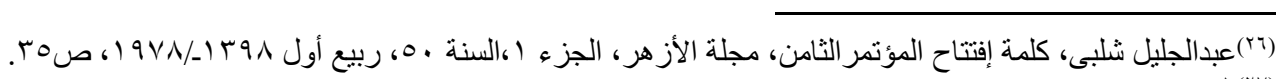

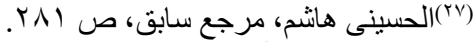

$$
\begin{aligned}
& \text { (ه) }
\end{aligned}
$$

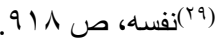


Muhammad Al-Bahi ${ }^{(30)}$, the Minister of Awqaf and Al-Azhar Affairs, welcomed the attendants at the first conference of the Islamic Research Academy in its first session. This conference discussed the problems and issues of Muslim societies and worked to solve them. For example, it discussed what colonialism did in Algeria to keep the Arabs of Algeria away from Islam. However, the Algerian Revolution broke out, and the conference denounced the problems faced by Muslims in Africa and the hostility of the missionaries. They demanded the scholars of the conference to find solutions to spread Islam in these regions, and prevent the missionaries from what they were doing towards African countries and building schools to spread their missionary thoughts, as they did in South Sudan ${ }^{(31)}$.

The researches discussed in the first conference of the Islamic Research Academy can be classified as follows

(A) Researches resisting the common enemy of Islam, colonialism, and Zionism as well as the hukm (ruling) governing the Muslim's struggle against them.

(B) Researches to unify the word of Muslims throughout the world, erasing the causes of alienation between them and removing the causes of sectarian strife.

(C) Researches in abstaining Islam from the curiosity and misunderstandings that may have deformed it image. Several studies have been studied in this regard on ijtihad: its past and present, and the falsifications between the rulings and sayings of Madhhabs.

(D) Researches in organizing economic and social relations between Muslims on a sound Islamic basis. Several research papers were prepared and studied relating to private property and financial resources in Islam, the right of the poor in the fortunes of the wealthy and international relations in Islam.

(E) Researches on the factors of the spread of Islam and the Arabs' role in this regard ${ }^{(32)}$.

${ }^{(30)}$ Muhammad Al-Bahi was born in al-Beheira governorate in 1905. He joined the mission of Mohamed Abdou at the University of Hamburg, Germany, during which he obtained a high diploma in the German language in 1934. In addition, he got his doctorate degree in philosophy, psychology and sociology, and was appointed as a teacher in the Faculty of Fundamentals of Religion after his return from Germany. Then, he became the head of the Department of Philosophy, Faculty of Arabic Language. Moreover, he represented Al-Azhar in many seminars, and he took the management of endowments and Al-Azhar affairs. His books were translated into English, Turkish and Indonesian, and he had many books, including "al-Islam walRiq". He died in 1983.

$$
\begin{aligned}
& \text { ـ ( للمزيد انظر : محى الدين الطعىى، مرجع سابق، ص ع ـ } 7 \text { ( ). }
\end{aligned}
$$

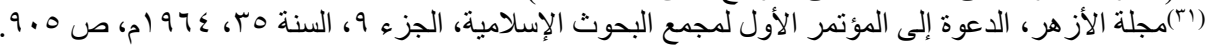

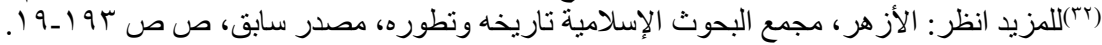


The religious and economic issues predominated the topics of discussion in this conference, as the number of researches reached 15 that focused on religious issues such as Ijtihad and fabrication of the rulings of Madhhabs. They included the deliberations of conference members and studies to the problems of abstaining Islam from the errors attributed to it, and removing the causes of sectarian differences between Muslims. The conference's focus on economic issues is due to reasons specific to the then historical era of Egypt, i.e., 1961, which was represented by issuing the socialist laws and nationalization.

The first Islamic Research Academy conference concluded several recommendations that were agreed upon by the participating Muslim scholars. These were as follows:

- Setting a positive plan to build the Muslim personality on the basis of Islamic principles that call for pride, freedom and dignity, and enable Muslims to confront their issues and prepare them to respond to any aggression against their rights in any Islamic country as Muslims are one nation.

- Informing Muslims around the world of the danger of Israel on Islam and Muslims, and inviting them to support the Palestinians against the occupation

- Developing a wise plan to call for the path of God and resist the challenges facing Islam.

- Diagnosing weaknesses in Islamic societies and working to remedy them.

- Working to issue fatwas and rulings derived from the origins and teachings of Islam.

- Providing the necessary means to increase the attention of all Islamic peoples to Arabic, the language of Qur'an.

- Supporting ties between Muslims and strengthening their links with the Islamic Research Academy, which was established to be a meeting place for the Islamic scholars and thought to guide and disseminate the Islamic call and prepare the preachers for this duty ${ }^{(33)}$.

Therefore, it can be said that one of the most important recommendations of this conference was to follow the means necessary to increase the attention of all Islamic peoples to Arabic, the language of the Holy Qur'an to raise awareness of it and teach it widely ${ }^{(34)}$.

The success of the first conference of the Research Academy in Cairo had a far-reaching resonance throughout Africa, and after their travel, many members sent telegrams of thanks to Al-Azhar Al-Sharif. These included

$$
\begin{aligned}
& \text { (Tr) }
\end{aligned}
$$

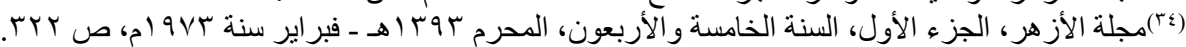


Tunisia, as the University of Al-Qarawiyyin sent a correspondence to the Honorable Dr. Abdullah Madi ${ }^{(35)}$, Deputy of Al-Azhar and the president of the conference, thanking Al-Azhar for its contributions and the proper administration of the conference. Also, the scholars of Morocco followed with great interest the successful steps recorded by the conference and demanded unity against the enemies. Abdel WahabDakrouri, the Chargé d'Affairs of Mali Embassy in Jeddah, sent a message of thanks to Dr. Mohamed Madi for this historic meeting of Muslim scholars and Azharites. He called for promoting Islam and confronting the problems facing Muslims around the world, especially in Africa ${ }^{(36)}$.

\section{(2) The Second Conference}

It was held in Muharram 1385 AH - May 1965 AD. Dr. Mahmoud Hoballah, Secretary General of the Islamic Research Academy, concerning setting this date, he stated that it was taken into account to hold it after the Muslim scholars accomplish their Hajj ${ }^{(37)}$.

Meanwhile, the Islamic world was clearly influenced with the problem of Palestine and Israel's allegations of its historical and religious rights in Palestine. They also examined some problems of economic nature such as banking transactions. The conference had to study the Muslims' view of the new generation, the elements of civilization in Islam, alongside with many other topics ${ }^{(38)}$.

The second conference of the Academy witnessed presenting increasing number of religious researcher. They were six researches out of 13, out of which six were in the economic and social fields and one research in the political field. The focus on the religious, economic and social issues can be attributed to the Academy members' desire to achieve the basic mission of the Academy, i.e., its cultural and societal missions ${ }^{(39)}$.

${ }^{(35)}$ He was born in February 1903 in the village of Asmaniya, Shoubrakhit district, al-Beheira Governorate. He memorized the Holy Quran in the kuttab of the village. In 1917, he joined the Alexandria Religious Institute, then joined the Higher Department in Al-Azhar and obtained a certificate of al-'Alameya in 1930 AD. He was appointed as a teacher at the said Institute, and in $1938 \mathrm{AD}$ he was appointed a professor for Islamic history at the Faculty of Fundamentals of Religion. Then, he was appointed secretary of Al-Azhar and the religious institutes until this position was abolished. He was appointed a general director of the religious institutes and then the deputy of Al-Azhar in 1962 AD. He retired in 1970.

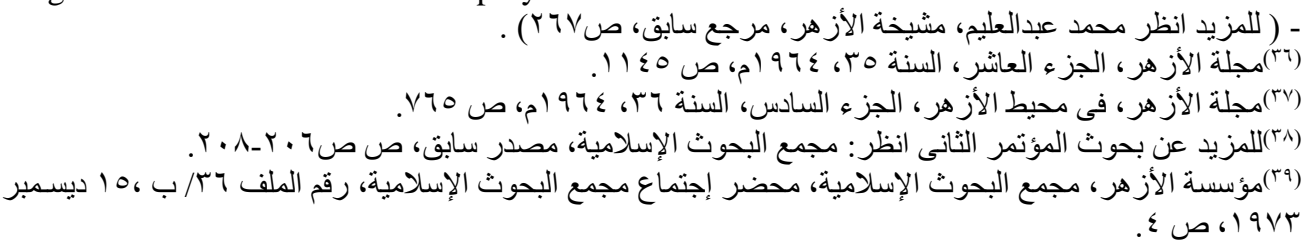


The second conference of the Islamic Research Academy concluded some important recommendations. The most important of which were as follows:

- To identify the practical means for spreading Islam and the call to God in various countries of the world and to discuss the method of financing these means so that the Academy goes ahead with its mission.

- The Islamic countries had to cooperate in everything affecting the Muslims' interests in their religious and worldly life.

- To mandate the Grand Imam Sheikh Al-Azhar to form the committees entrusted with researching the tasks identified and agreed upon by the scholars participating in the conference.

- That all the Muslims had to exert efforts to liberate Palestine, the usurped Islamic Arab country completely.

- Supporting the Palestine Liberation Organization in order to fulfill its duty to defend the usurped land in various fields, and that Islamic bodies and institutions in every Islamic country had to follow up the Palestinian issue and enlighten the public opinion with its aspects.

- Establishing Islamic centers in Jerusalem.

- The need to monitor books that spread deviation, whether Arabicized or composed. A law shall be developed to stipulate submitting these woks to a specialized authority before there printing and publication ${ }^{(40)}$.

\section{(3) The Third Conference}

It was held in Rajab 1386 AH - October 1966 AD. It discussed mainly a number of important religious issues as eight research papers were submitted to the conference, out of (12) researches. These were followed by three researches in the political field, where it reached three researches, then a research in the economic field. In order to face the attempts of tendentious orientalists, and their perseverance to raise doubts on the value of Hadith and the position of Sunnah, some of the presented researches aimed at correcting the misconceptions of orientalists and evangelized on Islam ${ }^{(41)}$.

The Muslim scholars participating in the third conference of the Islamic Research Academy recommended the necessity of joining efforts of Muslims, governments and individuals in order to direct their public and private lives in an Islamic destination. It assured the need to revive the Islamic heritage and the correct definition of Islam. The conference urged the Academy to

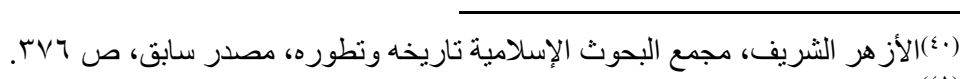

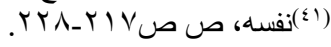


form a permanent body to bear the responsibility of introducing Islam and directing educational and cultural programs to the right Islamic destination.

It realized the necessity of establishing a fund to collect all Muslims contributions to finance the definition and spread of Islamic culture, reviving Islamic heritage and establishing Islamic centers. Moreover, it saw it necessary to purify Islamic societies from intellectual and moral invasion and guiding them to the perfection of Islamic teachings. The conference asked the Islamic countries to teach Arabic, the language of the Holy Qur'an at their schools to facilitate participation of non-Arab Muslims in studying the Qur'an and Sunnah of the Prophet ${ }^{(42)}$.

The General Secretariat of the Islamic Research Academy issued the third book of the conference, which included the researches that were delivered at its sessions held in October 1966 in Arabic and English. The book included twelve researches prepared by the members of the Academy and discussed in its meetings ${ }^{(43)}$.

\section{(4) The Fourth Conference}

It was held in Rajab 1388 AH - September 1968 AD. This conference witnessed an unusually large increase in the field of political research, which amounted to 21 researches out of a total of 28 research papers submitted to the conference. As for the religious researches, they were seven papers, including (compiling the Qur'an and writing it down, the character of Muslim, the hukm (ruling) of those left behind from jihad). This interest in political research more than the religious can be attributed to the nature of historical conditions that Egypt went through, including the June 1967 defeat and the burning of the Zionist occupation of Jerusalem. The conference presented what should Muslims have done in these circumstances facing the Islamic nation and Islam ${ }^{(44)}$.

At the end of the conference, the participating scholars condemned the Zionist entity and its aggression on the Arab territories. It called for the necessity of mobilizing all powers to confront this usurping entity by mobilizing the spiritual powers and deepening the Islamic values at schools, institutes, universities and mosques. There were also other Qur'anic, juristic, and social researches presented in this conference. It focused on the personality of Muslim as a human being, defining its features and

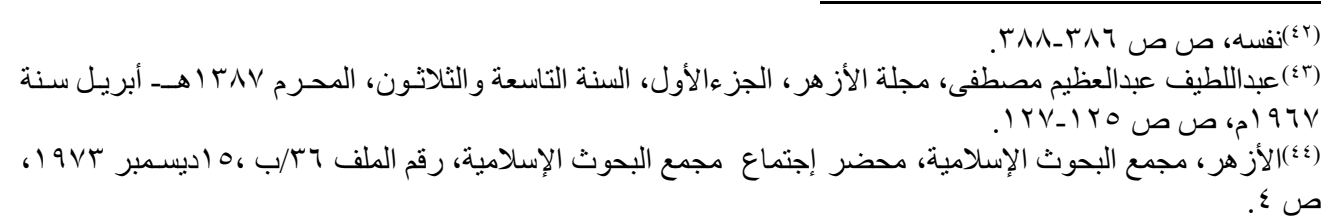


components, and clarifying its human rights in Islam and comparing that with human rights in the Western civilization ${ }^{(45)}$.

\section{(5)The Fifth Conference}

It was held in Muharram 1389 AH-1970 AD. It had a large number of religious researches, reaching 16 out of a total of 24 submitted to the conference. The increase is due to the conditions of the 1967 defeat, and the increasing calls to return to Islam as the original source of society, its solidarity and cohesion at this stage ${ }^{(46)}$.

Researches and studies were also presented on youth and their importance in society, how to protect them from intellectual deviations and how to support their faith, and revealing the falsehood of democracy in societies practicing methods of racial discrimination in some African countries. It shed light on the importance of mosques in raising the level of social awareness, and the great role of Al-Azhar in serving Islamic causes in Islamic countries ${ }^{(47)}$.

\section{(6)The Sixth Conference}

It was held in Muharram 1391 AH - March 1971, and religious research has increased in this conference, reaching 38 out of 40 researches submitted, and the political researches in the second place. These religious researches were presented during the first tenure of President Anwar Sadat as he sought the application of Sharia ${ }^{(48)}$.

In this conference, several important issues were discussed, including the Islamic unity and the conditions of Muslims at that time of separation and deviation from the way of God. It realized the necessity of unity to face the dangers threatening the Islamic nation. The crisis of Islamic publications was studied due to their decline versus the anti-religious publishing activity in general and anti-Islam in particular. The conference discussed the renewal of means of presentation and publishing to serve the Islamic religion. In addition, it highlighted the responses to the orientalists' claims regarding the Qur'anic readings, and recommended to urgently address these opinions and refute them scientifically to get rid of suspicions about the Islamic religion and the Holy Qur'an. The conference called for establishing "Dar al-FikrwalNashr al-Islami" - a publishing house - to serve the Islamic world in the field

$$
\begin{aligned}
& \text { (ه) للمزيد عن موضو عات وابحاث المؤتمر الرابع لمجمع البحـوث الإسـلامبة انظر : مجمع البحوث الإسـامية، مصدر }
\end{aligned}
$$

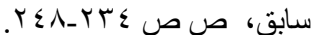

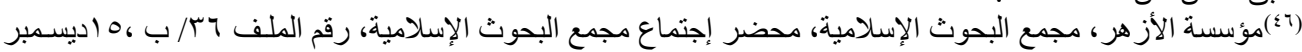

$$
\begin{aligned}
& \text { (19VT }
\end{aligned}
$$

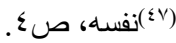

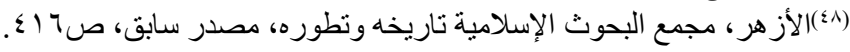


of composition, translation and publishing. It recommended the necessity to exchange more professors and students between countries at various educational levels ${ }^{(49)}$.

\section{(7) The Seventh Conference}

It was held in Sha'ban 1392 AH - September 1972 AD. Religious researches increased in this conference, reaching 21 out of the total of 38 papers submitted to the conference. They dealt with three main topics, namely the call to Islam, the economic and legislative researches, and research related to the problems of contemporary Islamic society. Each of these topics was handled separately in the book of the seventh conference of the Islamic Research Academy ${ }^{(50)}$.

At the end of the conference, the participating scholars recommended the necessity of coordination between the various bodies and offices that advocate Islam, and the necessity of generalizing religious education in the curricula of public education. In addition, it recommended establishing centers for memorizing the Holy Quran and the Sunnah of the Prophet for the Muslim children, inviting the media in Islamic countries to adopt the strong Islamic principles that foster moral values in the face of Zionism and colonialism that aimed at destroying the morals of Islamic societies ${ }^{(51)}$.

\section{(8) The Eighth Conference}

It was held in DhulQi'dah 1397 AH - October 1977 AD. Religious researches increased in this conference, reaching 23 out of the total of 28 papers submitted to the conference. This conference dealt with Islamic issues related to Islamic call abroad and the status of Islam and Muslims in African countries. It recommended that Al-Azhar and the Academy had to develop an Islamic constitution that would be available to any country that wants to adopt Islamic Sharia. The conference also discussed the conditions of minorities in some African countries andthe role of Al-Azhar University in the unity of Arab thought. It confirmed that the Research Academy need to prepare a long-term scientific plan to survey the linguistic conditions in Islamic societies, and that Al-Azhar had to establish a university college to specialize in studying the major Islamic languages and their interrelations with the Arabic language. Moreover, it recommended increasing its missions and scholarships to various Islamic countries and societies, provided being skillful in the language of the society to which they are dispatched. It

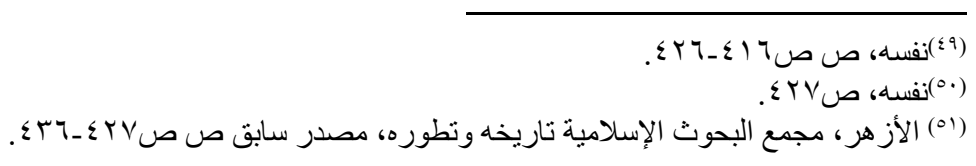


necessitated for every Muslim country to add the Arabic language to its educational curricula. This conference discussed the evangelizing document of Sheikh Abdullah bin Ali Al-Mahmoudi, in which he talked about Christianization in African countries, such as: (Algeria, Marrakech, Zanzibar, Nigeria, Ethiopia, and Eastern Africa) ${ }^{(52)}$.

Table (1): A statement clarifying and detailing the Number of Papers discussed by the Eight Conferences of the Islamic Research Academy during the period $(1964-1977)^{(53)}$.

\begin{tabular}{|l|l|l|l|l|l|}
\hline Field & $\begin{array}{l}\text { Researches } \\
\text { presented } \\
\text { in the } \\
\text { Religious } \\
\text { Field }\end{array}$ & $\begin{array}{l}\text { Researches } \\
\text { presented } \\
\text { in the } \\
\text { Political } \\
\text { Field }\end{array}$ & $\begin{array}{l}\text { Researches } \\
\text { presented } \\
\text { in the } \\
\text { Economic } \\
\text { Field }\end{array}$ & $\begin{array}{l}\text { Researches } \\
\text { presented } \\
\text { in the } \\
\text { Social } \\
\text { Field }\end{array}$ & $\begin{array}{l}\text { Total } \\
\text { number of } \\
\text { submitted } \\
\text { Researches }\end{array}$ \\
\hline First 1964 & 7 & 1 & 7 & - & 15 \\
\hline $\begin{array}{l}\text { Second } \\
1965\end{array}$ & 6 & 1 & 3 & 3 & 13 \\
\hline Third 1966 & 8 & 3 & 1 & - & 12 \\
\hline Fourth 1968 & 7 & 21 & - & - & 28 \\
\hline Fifth 1970 & 16 & 3 & 1 & 4 & 24 \\
\hline Sixth 1971 & 38 & 2 & - & - & 40 \\
\hline $\begin{array}{l}\text { Seventh } \\
1972\end{array}$ & 21 & 6 & 10 & 1 & 38 \\
\hline Eighth 1977 & 23 & 1 & - & 4 & 28 \\
\hline
\end{tabular}

Thus it turns out that the Islamic Research Academy held eight conferences during the period from (1964-1977) during which it discussed (126) researches in religious fields out of the (198) researches presented in them all.

$$
\text { (or) }
$$


It discussed (38) papers in the political field, (22) papers in the economic field, (12) papers in the social field ${ }^{(54)}$.

In 1976, the Islamic Research Academy participated in the first IslamicAfrican Conference held from May 3-5 in 1976 AD. The delegations of thirty-five African countries participated in this conference, and Sheikh Khalaf Al-Sayed Ali ${ }^{(55)}$, the Secretary-General of the Research Academy represented Al-Azhar in this conference. This conference worked on spreading the Islamic call and raising the word of God, combating atheism and dissolution and all anti-Islam currents. It discussed several topics including: publishing and memorizing the Holy Quran, spreading the Arabic language, the language of the Holy Qur'an among the children of Islamic peoples, coordination among the African Islamic organizations, the establishment of the Islamic-African Coordination Council, the Islamic call and the destructive currents. The conference ended with decisions and recommendations that truly demonstrated its success ${ }^{(56)}$.

Here are some of the most important decisions and recommendations adopted by the conference:

\section{First: In the field of publishing the Qur'an}

- studying the Holy Qur'an in public, private, elementary, and secondary schools as a basic subject and establishing communal associations to memorize and interpret it in each country

- Care to translate the meanings of Qur'an into different languages

- Examining the translations of its circulated meanings that were set by hostile groups and monitoring the circulated Mushafs

- The establishment of two permanent centers for memorizing the Qur'an, based in (Nouakchott) in Mauritania and (Kano) in Nigeria

- Dispatching proficient Quran reciters to African regions where there are Islamic minorities

- Establishing Qur'anic institutes in the middle level to graduate reciters acculturated in the general culture and establishing a high institute for the Qur'an to provide the Qur'anic schools with teachers ${ }^{(57)}$.

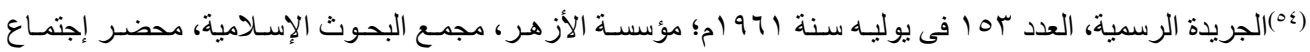

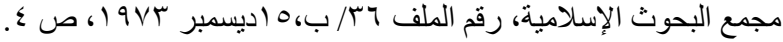

(55) Sheikh Khalaf Al-Sayyid was born on February 3, 1911 AD. He memorized the Holy Qur'an, then joined Al-Azhar, and obtained Ijaza - $t$ al-Da'wa (a license to preach) in 1941 $\mathrm{AD}$, then worked in preaching. He was appointed Secretary-General of the Islamic Research Academy in Sha'ban 1395 AH - August 1975 AD.

- (للمزيد أنظر : الأزهر، مجمع البحوث الإسلامية تاريخه وتطوره، مصدر سابق، صد . . (1).

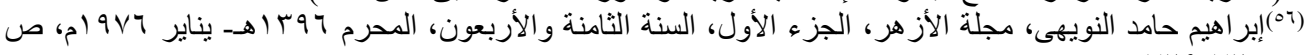

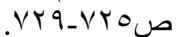

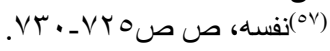




\section{Second: In the field of Spreading the Arabic Language}

- Standing in the face of attacks on the language of the Holy Qur'an by adopting its teaching at all educational levels,

- Developing and distributing books for its teaching,

- Setting up training courses for teachers of private schools and schools in the African continent,

- Supervising Arab schools where Non-Muslims assumed teaching the language of the Qur'an

- Spreading the Prophet's Hadith by developing pamphlets for children and adults.

- Asking the ministries of education in the Islamic world to designate cultural attachés - with Islamic moralities - to work on spreading the Arabic language,

- Generalizing Islamic programs that aimed at spreading the language of the Qur'an and work on using the latest curricula in the field of language teaching

- Finally, The conference recommended coordination between Islamic organizations ${ }^{(58)}$.

The Academy participated in many African conferences organized by a number of African bodies to serve the Islam in Africa. For example, the conference that was held in Nairobi, the capital of East Africa. Al-Azhar was represented in this conference by Sheikh Mohamed Al-Dahhan, Al-Azhar's envoy in Zanzibar. It also received a number of scholars from different countries of the world to participate in the conference to study and discuss issues related to the continent ${ }^{(\mathbf{5 9})}$.

The African countries were keen to invite Al-Azhar to send its representatives to attend the important conferences held by them. The administration of Al-Azhar also managed to facilitate the mission of its scholars to these conferences. The representative of Al-Azhar had to provide a full report on the conference, the researches and other activities after his return. He did so to assure the administration that their envoys were doing their duty perfectly ${ }^{(60)}$.

Considering the topics and issues discussed and addressed by the conferences of the Academy in Al-Azhar Al-Sharif from 1964 to 1977 AD, it becomes clear that they were attended by many Islamic research bodies to respond to the requirements of Islamic reality and Muslims' need at that time. The Academy worked to support the oppressed Muslim minorities in many

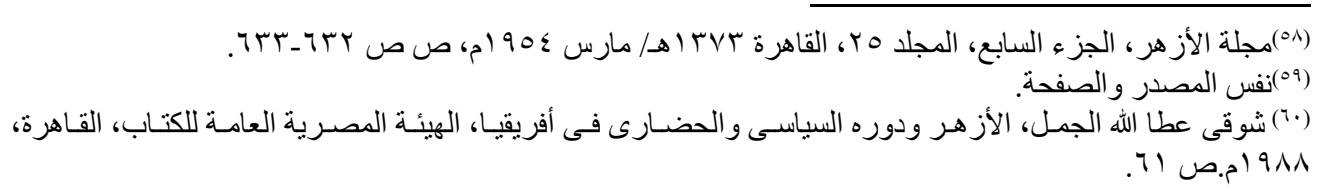


African countries, and to solve these problems faced by Muslims in Eritrea, Tunisia, Morocco and Algeria ${ }^{(61)}$.

\section{The Conclusion}

Therefore, it can be seen that the Islamic Research Academy was so significant in Al-Azhar through its establishment and participation in scientific conferences that bring together many Muslim scholars to discuss important issues in various Islamic countries. In addition, one can see how modern issues arisen in the Islamic community were discussed, such as the Palestinian cause and what the occupation authorities were doing towards AlQuds Al-Sharif, as well as what Muslims must do about this cause.

It also managed to study the dangers threatening the Islamic community in African countries, including evangelization dangers, and their distortions to Islamists and Muslims under the auspices of colonialism. The scholars participating in these conferences recommended the necessity of the Islamic organizations and institutions unity to stand up to what the missionaries were doing in Africa. They also were studying the ways of spreading Islam and Islamic culture in Africa. It called to the need to reject differences between Islamic and African countries and to unify their ranks towards the dangers threatening the Islamic community. 


\section{References}

(1) دار الوثائق القومية، ملف جس/ب، مؤسسة الأزهر الثريف، مجمع البحوث الإسلامية، محضر

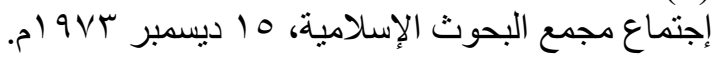
(Y) (الأزهر الثريف، مجمع البحوث الإسلامية تاريخه وتطوره، العيد الألفى للأزهر، القاهرة، (9N

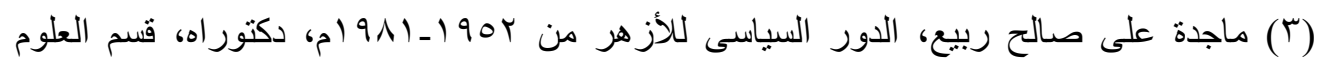

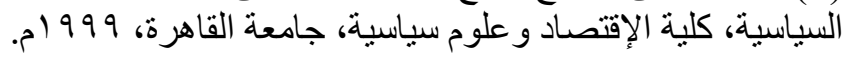

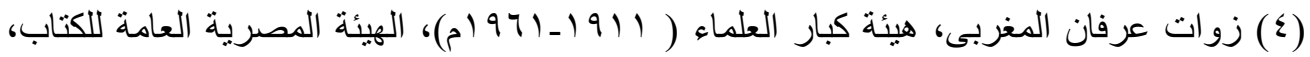

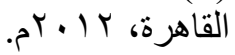

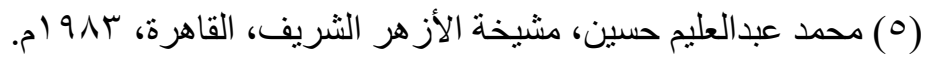

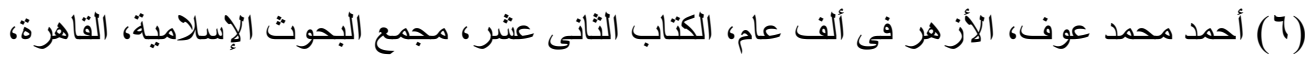
.م) $9 \mathrm{~V}$.

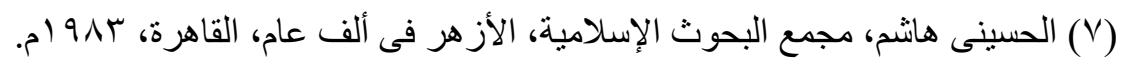
(^) م) 9 . (9) محمد السعدى فرهود، الأزهر الثريف " مرحلة التطوير"، الأزهر الثريف فى عيده الألفى،

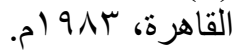
( • (1) محى الدين الطعمى، أسلاك الجوهر فى طبقات المعاصرين من شيوخ الأزهر، دار المعارف،

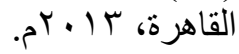
(1) (1) محمود عباس أحمد، الأزهر وأفريقيا، طن، المجلس الأعلى للآثار، الدار العالمية للنشر

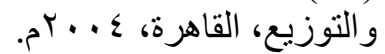

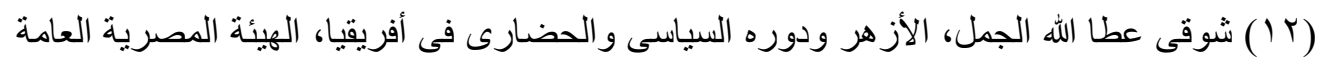
للكتاب، القاهرة،

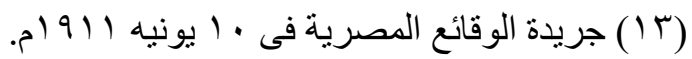

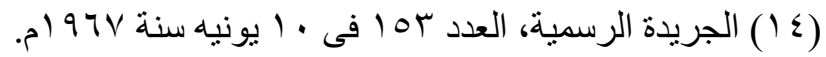

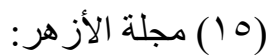
ـ الجزء (V) ) (

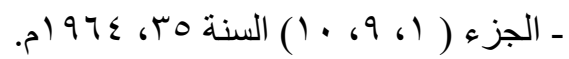

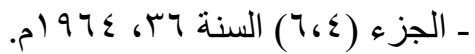

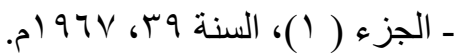

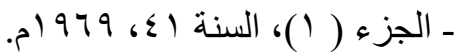

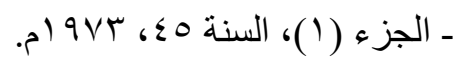

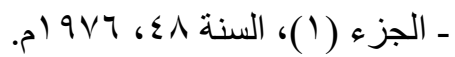

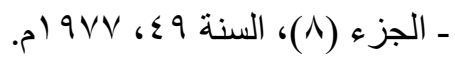

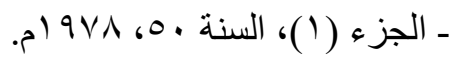
(7 (1) بوابة الحركات الإسلامية " موقع إلكترونى". 